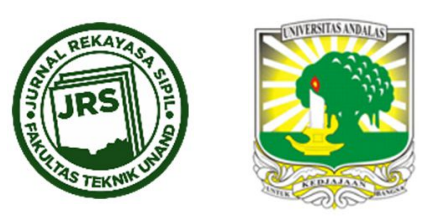

\title{
DESAIN KOLAM RETENSI PADA DAERAH ALIRAN SUNGAI BEKALA
}

\author{
ASRIL ZEVRI ${ }^{1}$ \\ Universitas Muhammadiyah Sumatera Utara \\ Email:ه asrilzevri19@gmail.com \\ Naskah diterima : 5 Juli 2019. Disetujui: 31 November 2019
}

\begin{abstract}
ABSTRAK
Kota Medan merupakan salah satu kota di Provinsi Sumatera Utara yang mengalami perubahan tata guna lahan akibat adanya pertambahan jumlah penduduk dengan tingkat kelahiran yang cukup tinggi. Perubahan tata guna lahan di sekitar DAS memberikan dampak yang buruk terhadap kemampuan menampung debit aliran. DAS Deli menjadi salah satu DAS yang mencakup wilayah Kota Medan dengan memiliki beberapa Sub Das salah satunya yaitu Sub DAS Bekala. Musim hujan dengan intensitas yang tinggi dan waktu yang lama mengakibatkan wilayah Kota Medan berubah menjadi daerah genangan banjir akibat meluapnya tinggi muka air banjir khususnya Sungai Bekala. Dampak banjir yang terjadi mengakibatkan kerugian bagi masyarakat di Kota Medan sehingga perlu adanya solusi yang efektif dalam pengendalian banjir Kota Medan. Tujuan penelitian ini untuk melakukan desain kolam retensi di DAS Bekala berdasarkan debit banjir kala ulang dengan debit kapasitas penampang Sungai Bekala. Lingkup kegiatan dalam penelitian ini yaitu menganalisa curah hujan harian rata-rata maksimum DAS Bekala, curah hujan harian maksimum kala ulang $2 \mathrm{~s} / \mathrm{d} 100$ tahun, debit banjir kala ulang 2 s/d 100 tahun, debit kolam retensi, dan desain kolam retensi. Hasil analisa studi menjelaskan yaitu debit kolam retensi DAS Bekala mencapai $94.37 \mathrm{~m}^{3} /$ det dengan lama waktu puncak banjir $3.37 \mathrm{jam}$. Simulasi volume total tampungan kolam retensi DAS Bekala mencapai $907,769.80 \mathrm{~m}^{3}$ dengan rencana dimensi luasan 50 ha dan tinggi $1.82 \mathrm{~m}$. Rencana dimensi bangunan intake lebar $4 \mathrm{~m}$, bukaan pintu $3 \mathrm{~m}$, dan tinggi $4 \mathrm{~m}$ dengan jumlah sebanyak 3 -unit dan dimensi bangunan pintu penguras lebar $2 \mathrm{~m}$, bukaan pintu $0.5 \mathrm{~m}$, dan tinggi $1 \mathrm{~m}$ sebanyak 1 unit.
\end{abstract}

Kata kunci : DAS Bekala, Curah Hujan, Debit Banjir, Debit Kapasitas, Kolam Retensi

\section{PENDAHULUAN}

Kota Medan merupakan salah satu kota di Provinsi Sumatera Utara yang mengalami pertambahan penduduk akibat adanya perpindahan penduduk dengan tingkat kelahiran yang cukup tinggi. Pertambahan jumlah penduduk mengakibatkan tata guna lahan di sekitar Daerah Aliran Sungai berubah menjadi daerah pemukiman yang mengakibatkan limpasan permukaan aliran mengalir dengan cepat. Secara geografis dan berdasarkan peta wilayah sungai wilayah Kota Medan dicakup oleh 2 Daerah Aliran Sungai yang cukup luas yaitu Daerah Aliran Sungai Deli dan Daerah Aliran Sungai Belawan. Salah satu Sub Das Deli yang berperan penting terhadap kebutuhan air baku untuk memenuhi kebutuhan DOI : https://doi.org/10.25077/jrs.15.2.90-102.2019 
masyarakat yaitu Daerah Aliran Sungai Bekala yang mengalir dan melewati jantung Kota Medan.

Musim hujan dengan intensitas yang tinggi mengakibatkan debit air sungai meningkat dan mengakibatkan debit banjir yang meluap dan menggenangi dataran pemukiman di sekitar daerah aliran sungai. Dataran banjir akibat volume air yang meluap berasal dari limpasan air permukaan yang sangat cepat dan mengakibatkan erosi di sekitar catchment area yang membawa sedimen menuju badan sungai. Sedimentasi di dasar sungai mengakibatkan pendangkalan sungai akibat adanya perubahan tata guna lahan menjadi daerah pemukiman sehingga daya resap air menjadi berkurang.

Potensi banjir di Kota Medan dapat mengakibatkan tinggi muka air banjir mencapai 1 sampai $3 \mathrm{~m}$ dari dataran sungai (Zevri, 2014). Jumlah daerah rawan banjir yang menggenangi wilayah Kota Medan mencapai 13 Kecamatan dengan 25 Kelurahan (BPBD Kota Medan, 2018). Dampak dari banjir mengakibatkan kerugian hampir mencapai milyaran rupiah dengan korban jiwa mencapai puluhan jiwa sehingga diperlukan adanya solusi dalam penanggulangan banjir secara terpadu dan menyeluruh.

Salah satu penanggulangan banjir yang dapat dilakukan secara struktural yaitu dengan merencanakan bangunan pengendali banjir seperti kolam retensi. Secara metode pendekatan kolam retensi banjir direncanakan dengan memahami karakteristik daerah aliran sungai, curah hujan, sistem jaringan sungai, profil penampang sungai, dan tata guna lahan.

\section{BANJIR DAN DAERAH ALIRAN SUNGAI}

\subsection{Potensi Banjir}

Banjir merupakan permasalahan umum yang terjadi di sebagian wilayah di Indonesia, terutama di wilayah padat penduduk misalnya di daerah perkotaan (Kodoatie, 2004). Potensi banjir terjadi akibat kapasitas penampang sungai tidak mampu dalam menampung debit maksimum pada saat kondisi banjir (Kodoatie, 2013). Kondisi tersebut dapat ditampilkan pada suatu sistem jaringan sungai khususnya di DAS Bekala yang tidak mampu menampung debit banjir rancangan kala ulang sehingga mengakibatkan DAS Deli sebagai sungai utama tidak mampu menahan total debit yang berasal dari Sub Das di sekitarnya dan mengakibatkan daerah genangan banjir. Prakiraan alokasi debit banjir dengan kapasitas DAS Deli dengan DAS Bekala ditampilkan pada Gambar 1 (Ginting, 2012).

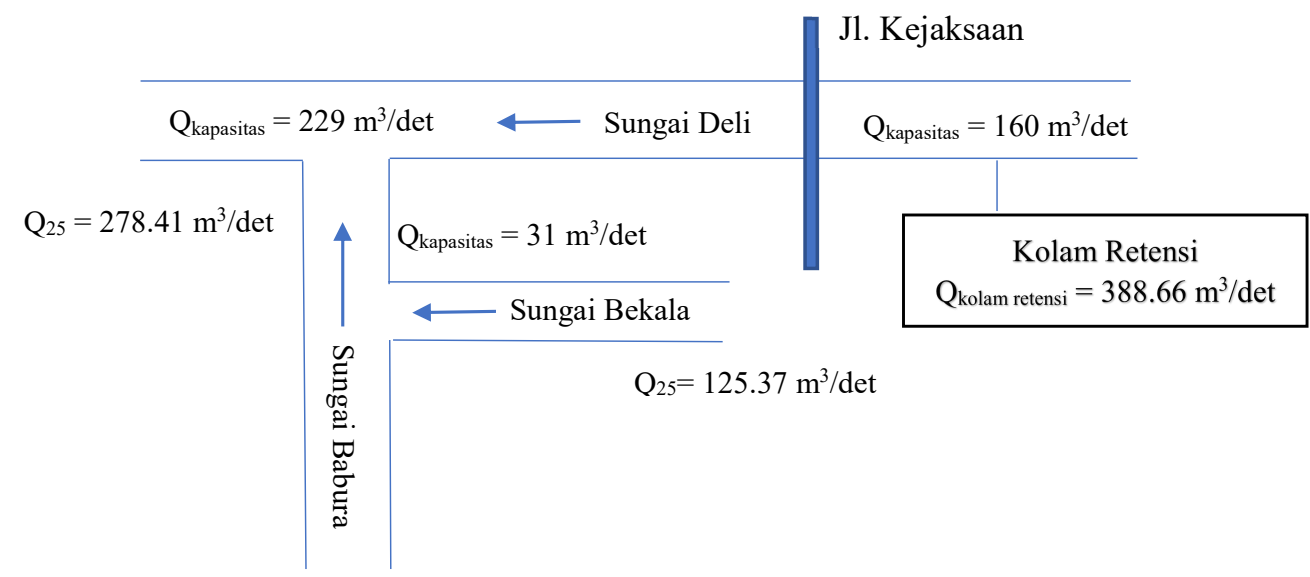

Gambar 1. Perkiraan Debit Banjir dan Debit Kapasitas DAS Bekala 


\subsection{Kolam Retensi}

Kolam retensi adalah suatu bak atau kolam yang dapat menampung atau meresapkan air sementara yang terdapat di dalamnya (Andayani, Djohan, \& Arlingga, 2017). Kolam retensi dibagi menjadi 2 macam tergantung dari bahan pelapis dinding dan dasar kolam, yaitu kolam alami dan kolam buatan. Pembangunan kolam retensi secara konsep dan pinsip yang digunakan yaitu tersedianya lahan yang cukup karena secara parsial berada di luar alur sungai dan tidak mengganggu sistem aliran sungai yang ada.

\subsection{Hidrologi Banjir}

Hidrologi banjir adalah ilmu yang berkaitan dengan proses terjadinya hujan maksimum yang berpotensi terjadinya debit banjir. Analisa hidrologi banjir terdiri dari curah hujan harian maksimum rata-rata yang terjadi merata di dalam cakupan DAS dengan metode polygon thiessen. Curah hujan harian rata-rata maksimum digunakan untuk menghitung curah hujan kala ulang dengan metode probabilitas distribusi yaitu normal, log pearson III, dan gumbel (Kamiana, 2011). Debit banjir kala ulang dihitung dengan menggunakan curah hujan kala ulang. Metode debit banjir yang digunakan yaitu HSS Nakayasu berdasarkan intensitas curah hujan jam-jaman dengan waktu puncak banjir untuk mengetahui besarnya potensi volume tampungan kapasitas kolam retensi.

\subsection{Hidraulika}

Hidraulika adalah ilmu yang berkaitan dengan perhitungan dimensi bangunan air berdasarkan debit aliran baik itu aliran minimum maupun maksimum. Volume tampungan kolam retensi dianalisa berdasarkan debit banjir rancangan kala ulang, debit kapasitas, dan debit kolam retensi. Perbedaan antara debit kapasitas penampang sungai dengan debit banjir rancangan kala ulang menghasilkan debit kolam retensi (Florince, Arifaini, \& Adha, 2015). Volume kapasitas tampungan kolam retensi diperoleh berdasarkan simulasi waktu puncak banjir dengan waktu normal yang diperoleh berdasarkan kurva grafik debit banjir HSS Nakayasu (Nugroho, Qomariyah, \& Koosdaryani, 2017). Dimensi kolam retensi direncanakan dengan metode persamaan volume yang menghasilkan ukuran dimensi luas kolam dengan kedalaman (Yudianto \& Roy, 2009). Bangunan pendukung kolam retensi yaitu pintu intake dengan fungsi untuk mengatur debit aliran maksimum menuju ke kolam retensi dengan pintu penguras yang berfugsi untuk mengatur debit aliran pada saat normal dari kolam retensi menuju sungai.

\section{METODOLOGI PENELITIAN}

\subsection{Metode Penelitian}

Metode penelitian dilakukan dengan dua cara yaitu secara kuantitatif dan kualitatif. Kuantitafif adalah metode yang dilakukan dalam pengambilan data baik itu data primer yang meliputi debit kapasitas sungai dan penampang sungai sementara data sekunder meliputi curah hujan dan peta daerah aliran sungai. Kualitatif adalah metode yang dilakukan dalam pengolahan data dengan menggunakan rumus dan persamaan yang relevan yang menghasilkan data berupa statistic dan numerik. Kesimpulan diperoleh dengan penjelasan secara induktif yaitu data-data pengamatan yang diperoleh dari lapangan dengan dukungan data dari instansi terkait dianalisa secara hidrologi dan hidraulika yang akan menghasilkan volume kapasitas tampungan DAS Bekala dengan rencana dimensi kolam retensi sebagai salah satu solusi dalam pengendalian banjir Kota Medan. Prosedur atau tahapan metodologi penelitian dijelaskan sebagai berikut. 
1. Analisa curah hujan harian maksimum rata-rata DAS Sungai Bekala

Luas pengaruh tiap stasiun penakar curah hujan digunakan untuk menghasilkan curah hujan harian rata-rata maksimum. Curah hujan harian maksimum tiap stasiun dikalikan dengan luas pengaruh tiap stasiun curah hujan atau dengan faktor thiessen (Triatmodjo, 2013). Rumus atau persamaan curah hujan harian rata-rata maksimum dengan polygon thiessen ditampilkan pada persamaan berikut ini.

$$
\bar{R}=R 1 \times F 1+R 2 \times F 2+R 3 \times F 3 \ldots \ldots+R n \times F n
$$

Di mana:

$\overline{\mathrm{R}} \quad=$ Curah hujan rata-rata harian maksimum $(\mathrm{mm})$

$\mathrm{R}_{1,2,3}=$ Curah hujan harian maksimum stasiun 1, 2dan $3(\mathrm{~mm})$

$\mathrm{F}_{\mathrm{t}, 1,2,3}=$ Faktor thiessen stasiun 1,2, dan 3

2. Analisa curah hujan kala ulang dengan distribusi kala ulang

Metode yang digunakan dengan analisa statistik (distribusi frekuensi) yaitu Normal, Log Pearson III, dan Gumbel. Rumus atau formula statistik distribusi probabilitas frekuensi dijelaskan sebagai berikut.

$$
X_{T}=X+K_{T} x S_{X}
$$

Di mana:

$\mathrm{X}_{\mathrm{T}} \quad=$ Curah Hujan Rencana dengan Periode Kala Ulang (Tahun)

$\overline{\mathrm{X}} \quad=$ Curah Hujan Rata-Rata Harian Maksimum (mm)

$\mathrm{K}_{\mathrm{T}} \quad=$ Faktor Frekuensi

$\mathrm{S}_{\mathrm{X}} \quad=$ Standar Deviasi

$$
\log X_{T}=\log X+K_{X} x \log _{x}
$$

Di mana:

$\log \mathrm{X}_{\mathrm{T}}=$ Curah Hujan Rencana dengan Periode Kala Ulang (Tahun)

$\overline{\log X}=$ Curah Hujan Rata-Rata Harian Maksimum (mm)

$\mathrm{K}_{\mathrm{T}} \quad=$ Faktor Frekuensi

$\mathrm{S}_{\log \mathrm{X}} \quad=$ Standar Deviasi

$$
X_{T=} X+\frac{\left\{Y-Y_{n}\right\}}{S_{n}} \times S_{x}
$$

Di mana:

$\underline{\mathrm{X}}_{\mathrm{T}} \quad=$ Curah Hujan Rencana dengan Periode Kala Ulang (Tahun)

$\overline{\mathrm{X}} \quad=$ Curah Hujan Rata-Rata Harian Maksimum (mm)

$\mathrm{Y} \quad=$ Reduced Variate

Yn = Reduced Mean

$\mathrm{Sx} \quad=$ Standar Deviasi dari Curah Hujan

Sn $\quad=$ Reduced Standard Deviasi

3. Uji distribusi curah hujan kala ulang

Uji kecocokan hasil curah hujan harian maksimum dengan periode kala ulang dilakukan untuk menentukan dari ketiga metode di atas nilai yang memenuhi syarat terhadap beberapa parameter statistik dapat digunakan untuk menganalisa debit banjir dengan periode kala ulang. Pemilihan metode yang digunakan dalam analisa debit banjir kala ulang 
diuji berdasarkan parameter yaitu koefisien variasi (Ck), koefisien skewness (Cs), dan koefisien kurtosis (Ck) (Satya, 2014). Nilai standar atau syarat uji distribusi curah hujan kala ulang dibandingkan dengan hasil analisa perhitungan parameter koefisien berdasarkan data curah hujan harian maksimum. Koefisien parameter yang diuji yaitu Koefisien skewness (Cs) dan Koefisien Kurtosis (Ck). Persamaan kedua koefisien ditampilkan sebagai berikut.

$$
C S=\frac{N}{(n-1)(n-2) S x^{3}} \sum(X i-\bar{X})^{3}
$$

Di mana:

$\mathrm{C}_{\mathrm{S}} \quad=$ Koefisien skewness

$\mathrm{X}_{\mathrm{i}} \quad=$ Nilai tengah

$\mathrm{X} \quad=$ Rata-Rata

$\mathrm{S}_{\mathrm{x}} \quad=$ Standar deviasi

$\mathrm{n} \quad=$ Jumlah data

$$
C k=\frac{x \sum_{i=1}^{n}\left(X i-\overline{x)^{4}}\right.}{(n-1)(n-2) S^{4}}
$$

Di mana:

$\mathrm{Cv} \quad=$ Koefisien variasi

$\mathrm{X}_{\mathrm{i}} \quad=$ Nilai tengah

$\mathrm{X} \quad=$ Rata-Rata

$\mathrm{n} \quad=$ Jumlah data

\section{Debit Banjir Kala Ulang HSS Nakayasu}

Metode debit banjir yang digunakan yaitu HSS Nakayasu dianalisa berdasarkan data luas catchment area, tata guna lahan, koefisien pengaliran, dan panjang sungai. Unsur perhitungan debit banjir dengan HSS Nakayasu diperhitungan berdasarkan waktu puncak banjir (Tp), waktu konsentrasi (Tg), dan waktu surut $\left(\mathrm{T}_{0.3}\right)$ (Sarminingsih, 2018). Bentuk persamaan HSS Nakayasu ditampilkan sebagai berikut.

$$
Q p=\frac{1}{3} \times A \times R \times\left(\frac{1}{3} x t p+t 0.3\right)
$$

Di mana:

$\mathrm{Q}_{\mathrm{p}} \quad=$ Debit puncak $\left(\mathrm{m}^{3} /\right.$ det

A = Luas Daerah Aliran Sungai $\left(\mathrm{km}^{2}\right)$

$\mathrm{T}_{\mathrm{p}} \quad=$ Waktu Puncak (jam)

$\mathrm{T}_{0.3} \quad$ = Waktu saat debit sama dengan 0.3 kali debit puncak (jam)

$\mathrm{R}_{0} \quad=$ Curah hujan (mm)

\section{Dimensi Kolam Retensi}

Desain dimensi kolam retensi diperhitungkan dengan selisih antara debit kapasitas Sungai Bekala dan debit banjir kala ulang 25 tahun. Debit yang berlebih atau yang meluap menjadi dasar dalam penentuan dimensi desain kolam retensi dengan simulasi antara inflow dengan outflow aliran. Simulasi penentuan volume tampungan kolam retensi diperhitungkan antara selisih inflow yaitu debit banjir kala ulang dengan outflow yaitu debit aliran yang berlebih dari kapasitas sungai dengan waktu aliran.

6. Dimensi bangunan Intake dan Penguras 
Bangunan intake pada kolam retensi berfungsi untuk mengatur debit aliran pada saat terjadinya kondisi banjir. Jenis bangunan intake yaitu berupa pintu sorong dengan rencana dimensi pintu dengan tinggi bukaan pintu pada saat pengambilan debit aliran maksimum atau banjir. Pintu penguras berfungsi untuk mengalirkan aliran dari kolam retensi pada saat muka air di sungai kembali normal. Rumus atau formula dalam perhitungan dimensi bangunan pintu intake dan penguras ditampilkan sebagai berikut.

$$
Q=\mu a b \sqrt{2 g z}
$$

\section{Di mana:}

$$
\begin{array}{ll}
\mathrm{Q} & =\text { Debit Aliran di Pintu }\left(\mathrm{m}^{3} / \text { det }\right) \\
\mu & =\operatorname{Koefisien} \text { Debit }(0.5<\mathrm{K}<1.0) \\
\mathrm{a} & =\text { Tinggi Bukaan Pintu }(\mathrm{m}) \\
\mathrm{b} & =\text { Lebar Pintu }(\mathrm{m}) \\
\mathrm{g} & =\text { Percepatan Gravitasi }\left(\mathrm{m} / \mathrm{s}^{2}\right) \\
\mathrm{z} & =\operatorname{Kehilangan} \text { Energi }(\mathrm{m})
\end{array}
$$

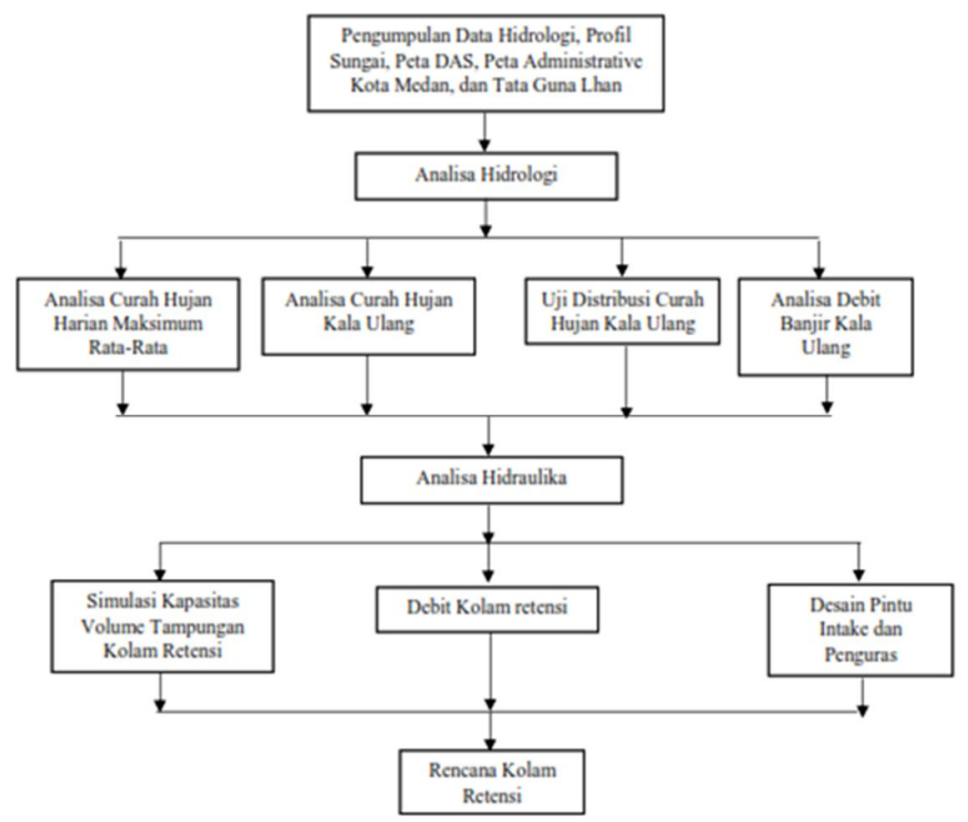

Gambar 2. Ruang Lingkup Penelitian

\subsection{Lokasi Penelitian}

Penelitian dilakukan di Daerah Aliran Sungai Bekala dengan luas catchment area 44.588 $\mathrm{km} 2$ dan panjang sungai $27.909 \mathrm{Km}$. Secara administrasi DAS Bekala berada di antara Kabupaten Deli Serdang dan Kota Medan yang ditampilkan pada Gambar 3. 


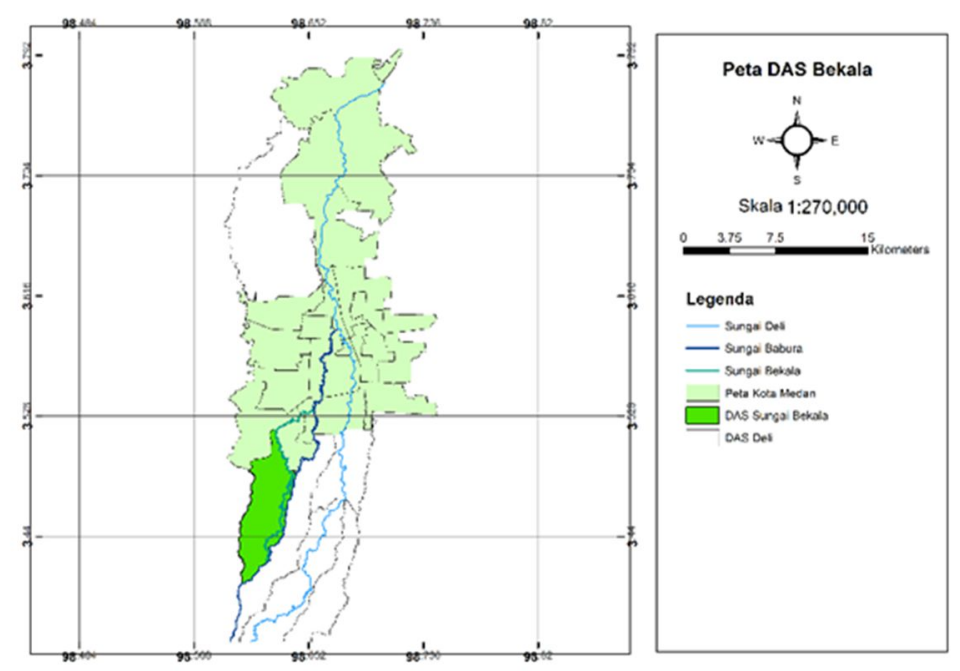

Gambar 3. Peta DAS Sungai Bekala

\section{ANALISA HIDROLOGI DAN HIDRAULIKA}

\subsection{Analisa Hidrologi}

Hasil curah hujan harian maksimum rata-rata kawasan dilakukan dengan metode polygon thiessen yang dianalisa berdasarkan titik stasiun penakar curah hujan di sekitar DAS Bekala yang mewakili Stasiun Curah Hujan Sibiru-biru untuk bagian hulu, Stasiun Curah Hujan Tuntungan untuk bagian tengah, dan Stasiun Curah Hujan Tanjung Selamat untuk bagian hilir. Ketiga titik stasiun curah huja n dibentuk sehingga membentuk suatu polygon tertutup dan menghasilkan luas pengaruh tiap stasiun curah hujan yang ditampilkan pada gambar 4 .

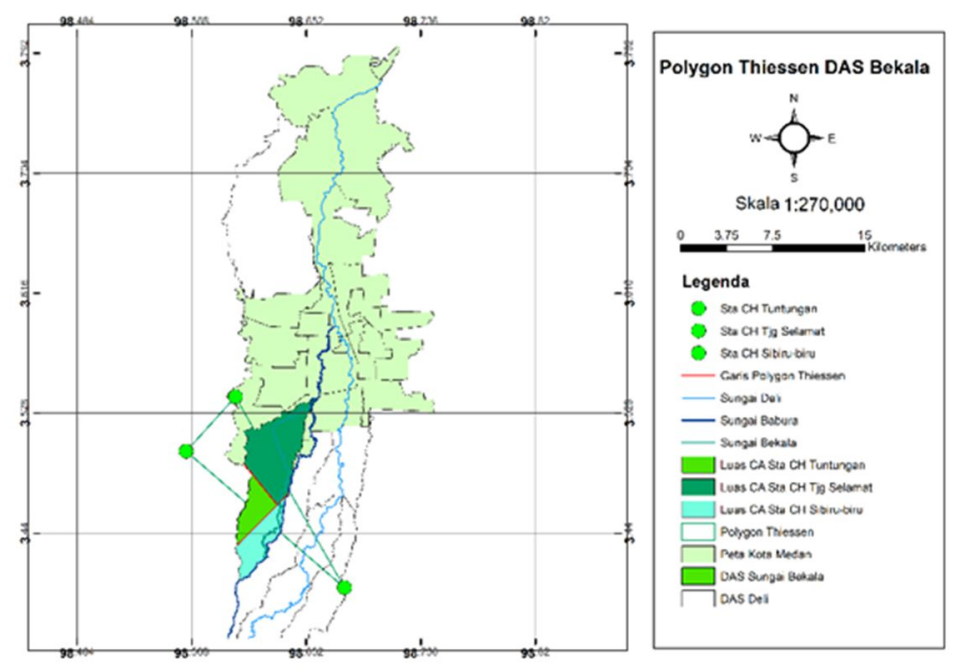

Gambar 4. Polygon Thiessen DAS Bekala

Hasil analisa dengan metode Polygon Thiessen menggambarkan luas pengaruh stasiun penakar curah hujan diwakili oleh 3 stasiun baik itu bagian hulu, tengah, dan hilir sungai. Luas pengaruh stasiun curah hujan dengan metode polygon thiessen ditampilkan pada Tabel 1. 
Tabel 1. Luas Pengaruh Stasiun Curah Hujan DAS Bekala

\begin{tabular}{ccc}
\hline $\begin{array}{c}\text { Stasiun Penakar Curah } \\
\text { Hujan }\end{array}$ & Luas & $\begin{array}{c}\text { Faktor } \\
\text { Thiessen }\end{array}$ \\
\hline Tjg Selamat & 25.455 & 0.57 \\
\hline Tuntungan & 8.15 & 0.18 \\
\hline Sibiru-Biru & 10.98 & 0.25 \\
\hline
\end{tabular}

Hasil analisa curah hujan rata-rata harian maksimum kawasan DAS Sungai Bekala ditampilkan pada Tabel 2.

Tabel 2. Hasil Analisa Curah Hujan Harian Rata-Rata Maksimum DAS Bekala

\begin{tabular}{cccccccc}
\hline No & $\begin{array}{c}\text { Tjg } \\
\text { Selamat }\end{array}$ & $\begin{array}{c}\text { Faktor } \\
\text { Thiessen }\end{array}$ & $\begin{array}{c}\text { Tuntunga } \\
\mathbf{n}\end{array}$ & $\begin{array}{c}\text { Faktor } \\
\text { Thiessen }\end{array}$ & $\begin{array}{c}\text { Sibiru- } \\
\text { Biru }\end{array}$ & $\begin{array}{c}\text { Faktor } \\
\text { Thiessen }\end{array}$ & $\begin{array}{c}\text { Rata- } \\
\text { Rata }\end{array}$ \\
\hline 1 & 185 & 0.57 & 219 & 0.18 & 143 & 0.25 & 180.87 \\
\hline 2 & 152 & 0.57 & 169 & 0.18 & 122 & 0.25 & 147.72 \\
\hline 3 & 119 & 0.57 & 140 & 0.18 & 111 & 0.25 & 120.87 \\
\hline 4 & 110 & 0.57 & 128 & 0.18 & 108 & 0.25 & 112.80 \\
\hline 5 & 107 & 0.57 & 106 & 0.18 & 108 & 0.25 & 107.06 \\
\hline 6 & 99 & 0.57 & 101 & 0.18 & 101 & 0.25 & 99.86 \\
\hline 7 & 91 & 0.57 & 104 & 0.18 & 100 & 0.25 & 95.59 \\
\hline 8 & 81 & 0.57 & 89 & 0.18 & 100 & 0.25 & 87.14 \\
\hline 9 & 75 & 0.57 & 87 & 0.18 & 83 & 0.25 & 79.16 \\
\hline 10 & 67 & 0.57 & 83 & 0.18 & 79 & 0.25 & 72.88 \\
\hline
\end{tabular}

Hasil analisa curah hujan harian rata-rata maksimum DAS Sungai Bekala menunjukan curah hujan harian rata-rata maksimum mencapai $180.87 \mathrm{~mm}$ dan minimum $72.88 \mathrm{~mm}$ dalam kurun waktu 10 tahun. dan termasuk dalam kategori curah hujan tinggi. Analisa curah hujan harian kala ulang $2 \mathrm{~s} / \mathrm{d} 100$ tahun dengan tujuan untuk memprediksi besarnya potensi curah hujan pada masa yang akan datang ditampilkan pada Tabel 3.

Tabel 3. Hasil Analisa Curah Hujan Harian Maksimum Dengan Periode Kala Ulang DAS Bekala

\begin{tabular}{ccccccc}
\hline \multirow{2}{*}{ Metode } & \multicolumn{6}{c}{ Curah Hujan Periode Kala Ulang (mm) } \\
& $\mathbf{2}$ & $\mathbf{5}$ & $\mathbf{1 0}$ & $\mathbf{2 5}$ & $\mathbf{5 0}$ & $\mathbf{1 0 0}$ \\
\hline Normal & 110.40 & 138.03 & 152.50 & 166.58 & 177.83 & 187.05 \\
\hline $\begin{array}{c}\text { Log Pearson } \\
\text { III }\end{array}$ & 104.68 & 124.54 & 153.41 & 179.04 & 198.69 & 218.84 \\
\hline Gumbel & 105.90 & 145.57 & 171.84 & 205.03 & 229.65 & 254.09 \\
\hline
\end{tabular}

Parameter tersebut diuji dengan syarat yang telah ditentukan. Syarat uji distribusi curah hujan kala ulang ditampilkan pada Tabel 4.

Tabel 4. Syarat Uji Distribusi Curah Hujan Kala Ulang

\begin{tabular}{cccc}
\hline Jenis & \multicolumn{3}{c}{ Syarat } \\
\cline { 2 - 4 } Sebaran & Cs & Ck & Cv \\
\hline Normal & $=0$ & - & $=3$ \\
\hline $\begin{array}{c}\text { Log Pearson } \\
\text { III }\end{array}$ & $\neq 0$ & - & $\neq 0$ \\
\hline Gumbel & $<1.1396$ & $<5.4002$ & - \\
\hline
\end{tabular}


Kedua persamaan digunakan untuk menganalisa uji distribusi curah hujan kala ulang dengan 3 metode dan dibandingkan dengan syarat uji yang ditampilkan pada Tabel 5.

Tabel 5. Hasil Uji Kecocokan Distribusi Koefisien Distribusi dengan Syarat Uji Kecocokan

\begin{tabular}{ccccccccc}
\hline Jenis & & Syarat & \multicolumn{4}{c}{ Hasil Perhitungan } & \multicolumn{2}{c}{ Perbandingan } \\
Sebaran & Cs & Ck & Cv & Cs & Ck & Cv & Cs & Ck \\
\hline Normal & $=0$ & - & $=3$ & 1.1816 & 3.5465 & 0.2980 & No OK & No OK \\
\hline $\begin{array}{c}\text { Log Pearson } \\
\text { III }\end{array}$ & $\neq 0$ & - & $\neq 0$ & 1.1816 & 3.5465 & 0.2980 & OK & OK \\
\hline Gumbel & $<1.1396$ & $<5.4002$ & - & 1.1816 & 3.5465 & 0.2980 & No OK & OK \\
\hline
\end{tabular}

Berdasarkan tabel di atas hasil uji kecocokan distribusi curah hujan harian maksimum kala ulang menjelaskan bahwasanya metode Log Pearson III menjadi metode yang terpilih dikarenakan parameter syarat uji kecocokan distribusi telah memenuhi syarat Koefisien skewness (Cs) dan Kurtosis (Ck). Hasil analisa debit banjir rancangan kala ulang DAS Bekala ditampilkan pada Tabel 6.

Tabel 6. Hasil Analisa Debit Banjir Kala Ulang DAS Bekala

\begin{tabular}{|c|c|c|c|c|c|c|c|}
\hline \multirow{2}{*}{$\begin{array}{c}\text { Wakt } \\
\mathbf{u} \\
\text { (jam) }\end{array}$} & \multirow{2}{*}{$\begin{array}{c}\text { Unit } \\
\text { Hidrograf } \\
\text { Qt } \\
\left(\mathrm{m}^{3} / \mathrm{dt}\right) \\
\end{array}$} & \multicolumn{6}{|c|}{$\begin{array}{c}\text { Grand Total Debit }\left(\mathrm{m}^{3} / \mathrm{d}\right) \\
\text { Kala Ulang (Tahun) }\end{array}$} \\
\hline & & 2 & 5 & 10 & 25 & 50 & 100 \\
\hline 0.00 & 0.000 & 0.35 & 0.35 & 0.35 & 0.35 & 0.35 & 0.35 \\
\hline 1.00 & 0.038 & 4.31 & 5.06 & 6.15 & 7.12 & 7.86 & 8.63 \\
\hline 2.00 & 0.200 & 21.25 & 25.21 & 30.97 & 36.09 & 40.01 & 44.03 \\
\hline 3.00 & 0.528 & 55.65 & 66.13 & 81.39 & 94.92 & 105.30 & 115.95 \\
\hline 3.37 & 0.698 & 73.45 & 87.31 & 107.48 & 125.37 & 139.10 & 153.17 \\
\hline 4.00 & 0.584 & 61.53 & 73.14 & 90.01 & 104.99 & 116.48 & 128.26 \\
\hline 5.00 & 0.442 & 46.62 & 55.40 & 68.16 & 79.49 & 88.18 & 97.08 \\
\hline 6.00 & 0.334 & 35.34 & 41.98 & 51.63 & 60.20 & 66.77 & 73.51 \\
\hline 7.00 & 0.253 & 26.81 & 31.83 & 39.13 & 45.61 & 50.58 & 55.68 \\
\hline 7.68 & 0.209 & 22.24 & 26.39 & 32.42 & 37.78 & 41.89 & 46.11 \\
\hline 8.00 & 0.197 & 21.01 & 24.93 & 30.63 & 35.69 & 39.57 & 43.55 \\
\hline 9.00 & 0.164 & 17.50 & 20.76 & 25.49 & 29.69 & 32.91 & 36.21 \\
\hline 10.00 & 0.136 & 14.59 & 17.29 & 21.22 & 24.71 & 27.38 & 30.12 \\
\hline 11.00 & 0.113 & 12.17 & 14.42 & 17.68 & 20.57 & 22.79 & 25.07 \\
\hline 12.00 & 0.094 & 10.17 & 12.03 & 14.73 & 17.14 & 18.98 & 20.87 \\
\hline 13.00 & 0.078 & 8.50 & 10.04 & 12.29 & 14.29 & 15.82 & 17.39 \\
\hline 14.00 & 0.065 & 7.11 & 8.40 & 10.26 & 11.92 & 13.19 & 14.49 \\
\hline 14.15 & 0.063 & 6.93 & 8.17 & 9.99 & 11.60 & 12.83 & 14.10 \\
\hline 15.00 & 0.056 & 6.19 & 7.30 & 8.91 & 10.34 & 11.44 & 12.56 \\
\hline
\end{tabular}

Debit banjir kala ulang DAS Bekala dengan periode kala ulang terjadi dengan waktu puncak banjir 3.37 jam. Besarnya debit banjir dengan periode kala ulang $2 \mathrm{~s} / \mathrm{d} 100$ tahun yaitu 73.45 $\mathrm{m}^{3} /$ det s/d $153.17 \mathrm{~m}^{3} /$ det. Kurva debit banjir kala ulang HSS Nakayasu ditampilkan pada Gambar 5 . 


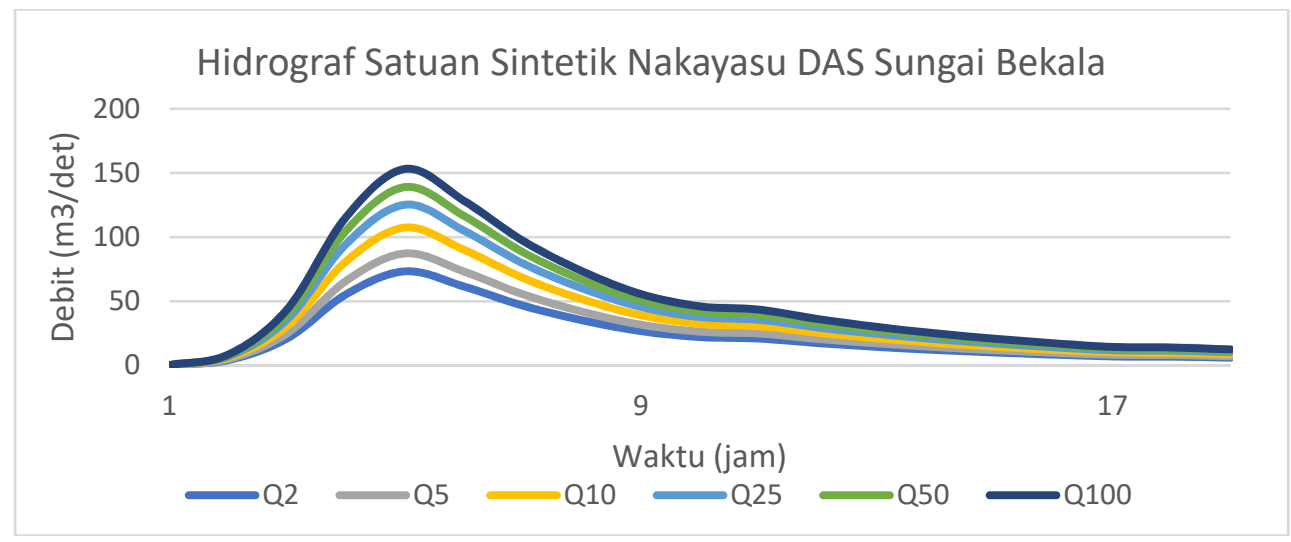

Gambar 5. Kurva Debit Banjir Kala Ulang DAS Bekala Dengan Metode HSS Nakayasu

\subsection{Analisa Hidrologi}

Debit banjir kala ulang yang digunakan untuk menganalisa debit kolam retensi yaitu debit banjir dengan periode kala ulang 25 tahun dikarenakan berdasarkan hasil curah hujan periode kala ulang dengan data curah hujan harian maksimum selama 10 tahun potensi debit banjir dengan periode kala ulang 25 tahun dapat terjadi di sekitar DAS Bekala. Simulasi volume tampungan kolam retensi DAS Bekala ditampilkan pada Tabel 7 .

Tabel 7. Simulasi Volume Tampungan Kolam Retensi DAS Bekala

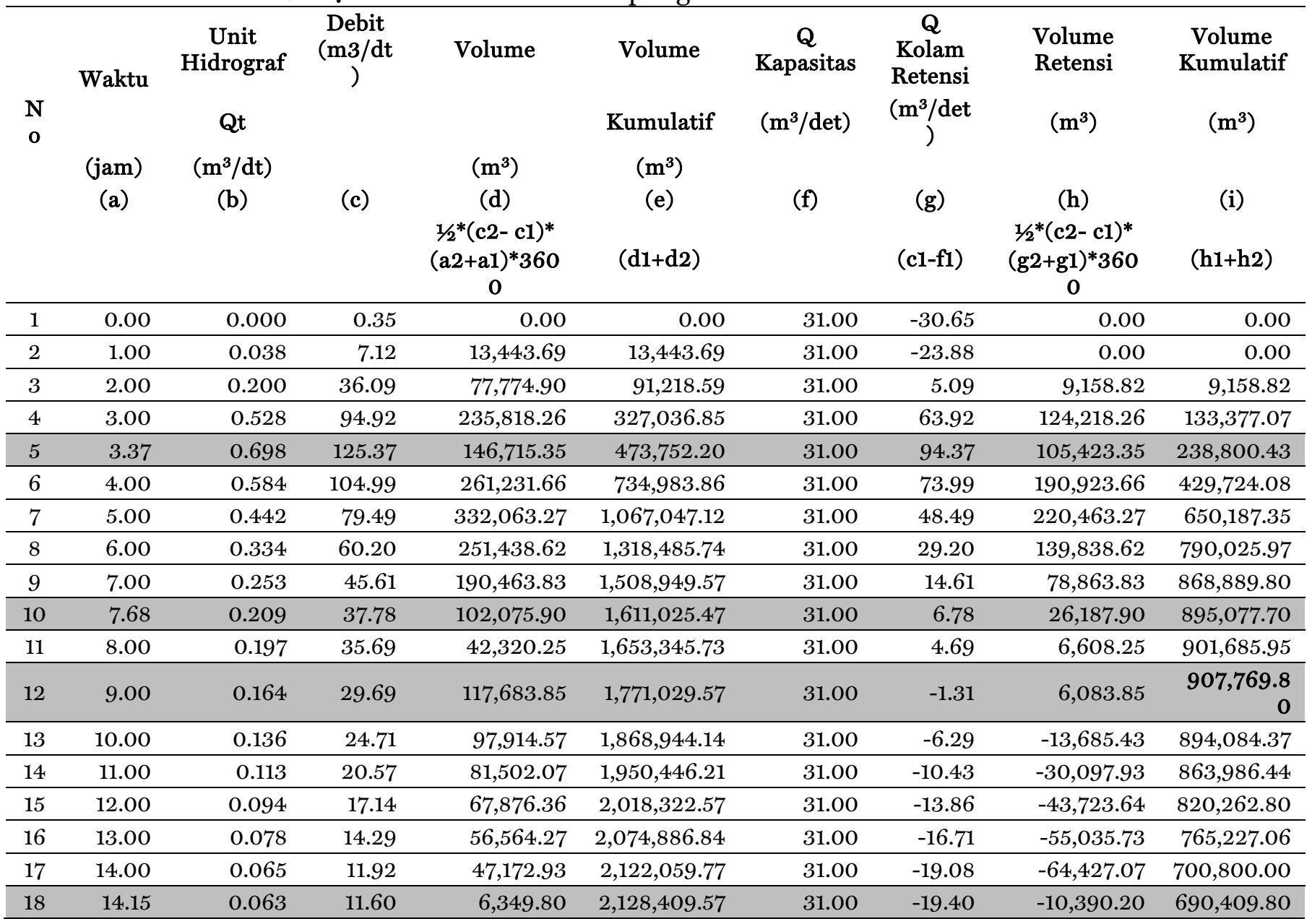


Hasil simulasi volume tampungan kolam retensi di atas diperoleh bahwasanya debit kolam retensi maksimum yaitu sebesar $94.37 \mathrm{~m}^{3} /$ det dengan waktu puncak $3.37 \mathrm{jam}$. Volume kumulatif tampungan kolam retensi yaitu 907,769.80 $\mathrm{m}^{3}$. Rencana dimensi kolam retensi dapat diperoleh dengan analisa sebagai berikut.

Dimensi Kolam Retensi = Luas Lahan Kolam $\mathrm{x}$ Tinggi Kolam

$$
\begin{aligned}
& =500000 \mathrm{~m}^{2} \times 1.82 \mathrm{~m} \\
& =907,769.80 \mathrm{~m}^{3}
\end{aligned}
$$

Bangunan pendukung kolam retensi yaitu pintu intake direncanakan dengan data-data sebagai berikut.

$Q_{\text {Max Kolam Retensi }}=94.37 \mathrm{~m}^{3} / \mathrm{det}$

$\mu=0.9$

$\mathrm{a}=$ ?

$\mathrm{b}=12 \mathrm{~m}(4 \mathrm{~m} \times 3$ Unit $)$

$\mathrm{g}=9.8 \mathrm{~m} / \mathrm{s}^{2}$

$\mathrm{z}=0.5 \mathrm{~m}$

Data-data di atas dimasukan ke dalam persamaan untuk memperoleh tinggi bukaan pintu yang dijelaskan sebagai berikut

$94.37 \mathrm{~m}^{3} / \mathrm{det}=0.9 \times \mathrm{a} \times 12 \mathrm{~m} \times 9.8 \mathrm{~m} / \mathrm{s}^{2} \times 0.5$

Sehingga diperoleh tinggi bukaan pintu yaitu $3 \mathrm{~m}$ dengan lebar pintu $4 \mathrm{~m}$ sebanyak 3 unit. Desain pintu penguras dianalisa sebagai berikut.

$Q_{\text {Normal Kolam Retensi }}=4.69 \mathrm{~m}^{3} / \mathrm{det}$

$\mu=0.9$

$\mathrm{a}=$ ?

$\mathrm{b}=2 \mathrm{~m}$

$\mathrm{g}=9.8 \mathrm{~m} / \mathrm{s}^{2}$

$\mathrm{z}=1.5 \mathrm{~m}$

Data-data di atas dimasukan ke dalam persamaan untuk memperoleh tinggi bukaan pintu yang dijelaskan sebagai berikut

$4.69 \mathrm{~m}^{3} /$ det $=0.9 \times$ a $\times 2 \mathrm{~m} \times 9.8 \mathrm{~m} / \mathrm{s}^{2} \times 1.5$

Sehingga diperoleh tinggi bukaan pintu yaitu $0.5 \mathrm{~m}$ dengan lebar pintu $2 \mathrm{~m}$ sebanyak 1 unit. Hasil rencana kolam retensi dengan bangunan pendukung ditampilkan pada Gambar 6 . 


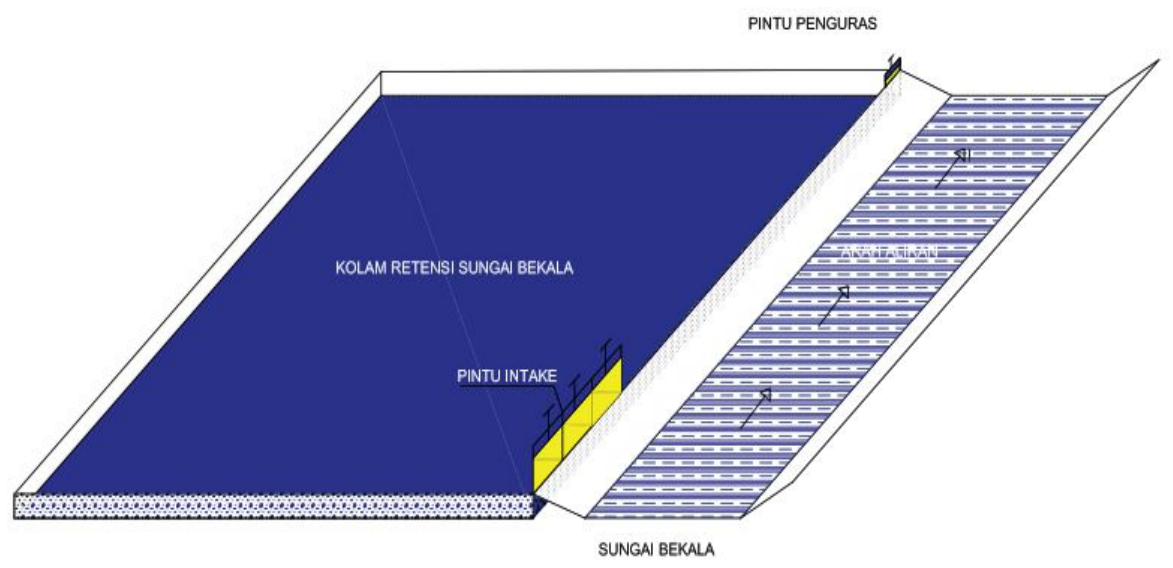

Gambar 6. Sketsa Rencana Desain Kolam Retensi DAS Bekala

Rencana dimensi kolam retensi DAS Bekala memilki potensi dalam mengurangi volume banjir DAS Babura sehingga mengurangi debit banjir di bagian hilir DAS Deli yang dikelilingi oleh daerah pemukiman. Kondisi ini dapat ditampilkan dalam bentuk skema alokasi debit banjir rancangan, debit kapasitas, dan debit kolam retensi sesudah adanya pembangunan kolam retensi yang ditampilkan pada Gambar 7 .

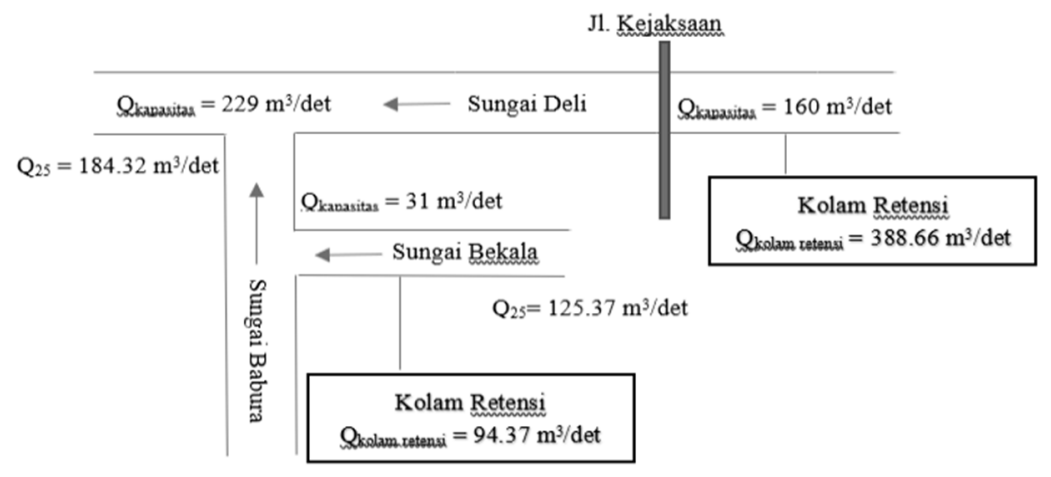

Gambar 7. Skema Alokasi Debit Kolam Retensi DAS Bekala

Skema alokasi debit kolam retensi di atas menunjukan bahwasanya dengan adanya pembangunan kolam retensi di DAS Bekala dapat mengurangi debit banjir di DAS Babura dengan periode kala ulang 25 tahun sebesar $94.37 \mathrm{~m}^{3} /$ det. Kondisi ini juga mengurangi debit banjir di bagian hilir muara Sungai Deli sebesar $44.68 \mathrm{~m}^{3} /$ det di mana $Q_{25}$ Deli sebelum adanya pembangunan $278.41 \mathrm{~m}^{3} /$ det setelah adanya pembangunan $\mathrm{Q}_{25}$ berkurang menjadi $182.43 \mathrm{~m}^{3} /$ det.

\section{KESIMPULAN}

Potensi debit banjir kala ulang yang terjadi di DAS Bekala berdasarkan hasil analisa debit banjir rancangan yaitu sebesar $Q_{25} 125.37 \mathrm{~m}^{3} /$ det. Debit kapasitas penampang Sungai Bekala $Q_{\text {kapasitas }} 31 \mathrm{~m}^{3} /$ det sehingga dengan simulasi volume kapasitas kolam retensi dengan waktu puncak banjir 3.37 jam diperoleh volume tampungan kolam retensi DAS Bekala mencapai $907,769.80 \mathrm{~m}^{3}$. Luas pemanfaatan yang dibutuhkan atau direncanakan dalam pembangunan mencapai 50 Ha dengan kedalaman kolam $1.82 \mathrm{~m}$. Bangunan pendukung pintu intake direncanakan dengan lebar $4 \mathrm{~m}$ dan bukaan pintu $3 \mathrm{~m}$ sebanyak 3 unit 
sementara pintu penguras direncakan dengan lebar $2 \mathrm{~m}$ dan bukaan pintu $0.5 \mathrm{~m}$ sebanyak 1 unit.

\section{DAFTAR PUSTAKA}

Andayani, R., Djohan, B., \& Arlingga, K. A. (2017). Penanganan Banjir Dengan Kolam Retensi (Retarding Basin) di Kelurahan Gandus Kota Palembang. JURNAL TEKNIK SIPIL, 7(1), 27-33.

BPBD Kota Medan. (2018). Laporan Dampak Kerugian Banjir Kota Medan. Medan: BPBD Kota Medan.

Florince, F., Arifaini, N., \& Adha, I. (2015). Studi Kolam Retensi sebagai Upaya Pengendalian Banjir Sungai Way Simpur Kelurahan Palapa Kecamatan Tanjung Karang Pusat. Jurnal Rekayasa Sipil dan Desain, 3(3), 507-520.

Ginting, M. (2012). Studi Potensi dan Mitigasi Banjir Kota Medan. Paper presented at the Prosiding Seminar Nasional-1 BMPTTSSI USU, Medan.

Kamiana, M. (2011). Teknik Perhitungan Rencana Debit Rencana Bangunan Air. Yogyakarta: Graha Ilmu.

Kodoatie, R. J. (2004). Pengelolaan Sumber Daya Terpadu. Yogyakarta: Andi.

Kodoatie, R. J. (2013). Rekayasa dan Manajemen Banjir Kota. Yogyakarta: Andi.

Nugroho, A., Qomariyah, S., \& Koosdaryani, K. (2017). Analisis Perencanaan Lahan Kolam Retensi di Kawasan Semanggi Kota Surakarta. Matriks Teknik Sipil, 5(3).

Sarminingsih, A. (2018). Pemilihan Metode Analisis Debit Banjir Rancangan Embung Coyo Kabupaten Grobogan. Jurnal Presipitasi: Media Komunikasi dan Pengembangan Teknik Lingkungan, 15(1), 53-61.

Satya, T. M. (2014). Studi Normalisasi Sungai Sampean Sebagai Upaya Pengendalian Banjir. Jurnal Teknik Pengairan Universitas Brawijaya.

Triatmodjo, B. (2013). Hidrologi Terapan. Yogyakarta: Beta Offset.

Yudianto, D., \& Roy, A. F. (2009). Pemanfaatan Kolam Retensi Dan Sumur Resapan Pada Sistem Drainase Kawasan Padat Penduduk. JURNAL TEKNIK SIPIL, 5(2), 103-121.

Zevri, A. (2014). Analisis Potensi Resiko Banjir Pada DAS Yang Mencakup Kota Medan Dengan Menggunakan Sistem Informasi Geografis (SIG).

Zevri, A. (2017). Analisis Volume Tampungan Kolam Retensi Das Deli Sebagai Salah Satu Upaya Pengendalian Banjir Kota Medan. Jurnal Rekayasa Sipil (JRS-Unand), 13(2), 113-122. 